\title{
Bartonella quintana
}

National Cancer Institute

\section{Source}

National Cancer Institute. Bartonella quintana. NCI Thesaurus. Code C86187.

A species of Gram-negative, rod shaped bacteria assigned to the phylum Proteobacteria.

This species is nonmotile, oxidase positive, indole and urease negative, and

nonhemolytic. B. quintana causes trench fever. 